\title{
Plantlet Regeneration of Somatic embryos from Leaf Explants of Mentha arvensis(L.) A medicinally important Plant
}

\author{
Sammaiah D. ${ }^{1}$, Odelu G. ${ }^{2}$, Venkateshwarlu M. ${ }^{3}$, Srilatha T. ${ }^{4}$, Anitha Devi U. ${ }^{5}$, Ugandhar T. ${ }^{6}$ \\ ${ }^{1}$ Department of Botany, Govt. Degree College, Huzarabad, (T.S) \\ ${ }^{2}$ Department of Botany, Govt. Degree College, Jammikunta, (T.S) \\ ${ }^{3}$ Department of Botany, Kakatiya University, Warangal, (T.S) \\ ${ }^{4}$ Department of Botany, Govt. Degree \& PG College for Women, Warangal, (T.S) \\ ${ }^{5}$ Department of Botany, Govt. Degree \& PG College for Women, Karimnagar, (T.S) \\ ${ }^{6}$ Department of Botany, SRR Govt. Degree \& P.G College, Karimnagar, (T.S)
}

\section{Email address:}

tugandharbiotech@gmailcom.in (Ugandhar T.)

\section{To cite this article:}

Sammaiah D., Odelu G., Venkateshwarlu M., Srilatha T., Anitha Devi U., Ugandhar T.. Plantlet Regeneration of Somatic embryos from Leaf Explants of Mentha arvensis(L.) A medicinally important Plant. Agriculture, Forestry and Fisheries. Vol. 4, No. 4, 2015 , pp. $173-178$. doi: 10.11648/j.aff.20150404.14

\begin{abstract}
The present study was conducted with the aim of evaluating some of the factors that influence induction and plantlet regeneration of somatic embryos in Mentha arvensis ( L) var piperascens Holmes (menthol or Japanese mint)since there are no available reports on Somatic embryogenesis and regeneration of plantlet in this medicinally important plant species. Leaves from plants growing under temporary shed were cultured on Murashige and Skoog medium fortified with (0.5$5.0 \mathrm{mg} / \mathrm{L})$ Napthlene acetic acid (NAA) $+(0.5 \mathrm{mg} / \mathrm{L})$ Thidizuron(TDZ). High frequency of somatic embryo formation was found at $(2.5 \mathrm{mg} / \mathrm{L}) \mathrm{NAA}+(0.5 \mathrm{mg} / \mathrm{L}) \mathrm{TDZ}$ in leaf explants respectively, Secondary somatic embryogenesis was also observed when primary somatic embryos were sub cultured same somatic embryo induction medium well developed cotyledonary stage embryos were germinated on MS medium supplemented with $(0.5 \mathrm{mg} / \mathrm{L})$ (NAA) $+(0.5-5.0 \mathrm{mg} / \mathrm{L}) \mathrm{TDZ}$ maximum $80 \%$ of somatic embryos germination and plant let formation was found at $(2.5 \mathrm{mg} / \mathrm{L}) \mathrm{NAA}+(0.5 \mathrm{mg} / \mathrm{L})$ (TDZ). The post translation survival rate of plants was $80 \%$ plants and flowers formation were morphological similar to the mother plants.
\end{abstract}

Keywords: Leaf Explants NAA (Napthlene Acetic Acid), TDZ (Thidizuron), Mentha arvensis (L), Somatic Embryos and Regeneration

\section{Introduction}

Mentha ravensis (Linn). var piperascens Holmes (menthol or Japanese mint) is an industrial crop that is widely cultivated for its essential oil from which menthol is crystallized. The essential oil, menthol and terpenes of the dementholated oil of $M$. arvensis are variously used in the food, perfumery and pharmaceutical industries. Improvement in the pest and disease tolerance and other adaptive characters determining the yield and quality of essential oil will make mint cultivation more economical. Construction of the desired $M$. arvensis genotypes will require transfer of specific foreign genes into the crop. Efficient procedures are required to regenerate plants from the transformed cells and for rapid micro-propagation of plant(s) of selected genotype(s). In vitro high efficiency procedures for cell and callus cultures and shoot regeneration from axillary buds and leaf explants have been reported in some species of the genus Mentha, especially the commercially important species $M$. piperita and M. spicata (Lin and Staba 1961; Cellarova 1992).

Total production of Mentha matches more than 32,000 MT per year and India is considered one of the largest producer and exporter with $27 \%$ commodity market share. Corn Mint is valued as multimillion cash crops for its multipurpose uses in the field of pharmaceuticals cosmetics as well as flavouring of food and beverages, oral preparations, such as toothpastes, dental creams and mouth washes. Green leaves of plants are used formaking chutney and for flavouring culinary preparation vinegar, flavour liqueurs, breads, salads, soups, cheese jellies, spice mixtures for many processed 
foods as well as in herbal tea (Moreno et al., 2002; Kofidiset al., 2006; Yadegarinia et al., 2006).

Mint plant is used as insect repellent, anaesthetic, galactofuge, refrigerant, stimulant, stomachic and excellent gastric organic stimulant (Budavari et al., 1989; Gulluceet al., 2007). Many authors worked on in vitro production of Mentha species using different explants viz., nodes, internodes, axillary buds and leaf discs. (Karasawa and Shimizu 1980, Rech and Pires, 1986, Van Eck and Kitto, 1990, Kukreja et al., 1992, Sato et al., 1993, Caissard et al., 1996, Reed, 1999). Preliminary work on in vitro regeneration of $M$. arvensis was carried out by several investigators but the results exhibited low efficiency of shoot regeneration from nodal explants.

Somatic embryo genesis offers great potential in plant multiplication and crop improvement for efficient cloning and genetic transformation (Ammiratio 1987, Roberts et.al., 1995). It is an alternative and efficient method for plant propagation over regeneration via organogenesis. Somatic embryos are believed to originate from single cell while organogenesis is through collective organization of cell. Therefore the plants derived from somatic embryos tend to be genetically alike; in addition somatic embryos are bipolar structures with root and shoot apices that can easily be developed into complete plantlets.

Embryos formed in cultures have been variously regenerated as accessory embryos, adventive embryos, embryoids and supernumerary embryos. Kohlenbach (1978) has proposed the following classification of embryos.

1. Zygotic embryos- those formed by fertilized egg or the zygote.

2. Non- Zygotic embryos- those formed by cells other than the zygote.

i. Somatic embryos- those formed by the sporophytic cells (except zygote) either in vitro or in vivo. Such somatic embryos arising directly from other embryos or organs (stem embryos in carrot and butter cup) are termed adventive embryos.

ii. Parthenogenetic embryos - those formed by unfertilized egg.

iii. Andorogenic embryos-those formed by the male gametophyte (microspore pollen grains).

In Somatic embryogenesis the embryo regenerate from somatic cells, tissues or organs either de novo or directly from tissues (Adventive origin) which in the opposite of zygotic or sexual embryogenesis. Various terms for nonzygotic embryos have been reported in literature such as adventive embryo (somatic embryos arising directly from other organs or embryos) parthenogenetic embryos (those formed by the unfertilized egg) and androgenetic embryos (formed by the male gametophyte). However in general context somatic embryos are those which are formed from the somatic tissue in culture, i.e. In vitro conditions. In sexual embryogenes is the act of fertilization triggers the egg cell to develop into an embryo, however it is not the monopoly of the egg to form an embryo. Any cell of the gametophytic (embryo-sac) or sporophytic tissue around the embryo-sac may give rise to an embryo, cells of the nucellus or linear integument may develop into embryos in the members of Rutaceae family. There are examples of embryos arising from endospermal cells also. However, the rate of multiplication is very low. In the present communication, we report reproducible method for in vitro plant regeneration via somatic embryogenesis in $M$. arvensis var piperascens Holmes (menthol or Japanese mint) from leaf explants using various cytokinins especially TDZ.

\section{Methodology}

\subsection{Plant Material}

Seeds of $M$. arvensis var piperascens Holmes (menthol or Japanese mint) were collected. From CIMAP (Central Institute of Medicinal Aromatic Plant Uppal. Hyderabad). Seeds which were initially soaked overnight and then washed with running tap water for $30 \mathrm{~min}$ to remove adherent particles, thoroughly washed seeds were then immersed in 5\% (v/v) Teepol for $10 \mathrm{~min}$ and then rinsed 3 times with sterile double distilled water. This was followed by the surface sterilization with $05 \%(\mathrm{~m} / \mathrm{v}) \quad \mathrm{HgCl}_{2}$ under the sterile conditions for $5 \mathrm{~min}$. these were rinsed 5 times in sterile double distilled water to remove all traces of $\mathrm{HgCl}_{2}$ the sterilized seeds were then placed on to the basal Murashige and Skoog (1962) medium for germination.

\subsection{Culture Media and Culture Conditions}

Leaf (6 weeks old ) explants from axenic seedlings were placed on MS medium supplemented with $30 \mathrm{gm} / \mathrm{L}$ sucrose along with different combinations of NAA $(0.5-5.0 \mathrm{mg} / \mathrm{L})$ $+0.5 \mathrm{mg} / \mathrm{L}$ TDZ respectively. The $\mathrm{pH}$ of medium was adjusted to 5.8 prior to autoclaving $121^{\circ} \mathrm{C}$ for $15-20 \mathrm{~min}$. All the cultures were incubated under $16 / 8 \mathrm{~h}$ light / dark photo period at $25 \pm 2^{\circ} \mathrm{C}$. a light intensity of $40 \mu \mathrm{mol} \mathrm{m}^{-2} \mathrm{~s}^{-1}$ was provided by cool- white fluorescent tubes. The cultures were transferred to fresh medium after an interval of 4 weeks.

For germination and plantlet formation somatic embryos were transferred to MS medium supplemented with $(0.5$ $\mathrm{mg} / \mathrm{L}) \mathrm{NAA}+(0.5-5.0 \mathrm{mg} / \mathrm{L})$ TDZand incubated under the same culture conditions.

\section{Results}

Results on somatic embryogenesis in $M$. arvensis are presented in (Table-1) leaf cultured on various concentrations of NAA $(0.5-5.0 \mathrm{mg} / \mathrm{L})$ in combination with $(0.5 \mathrm{mg} / \mathrm{L}) \mathrm{TDZ}$ become swollen and generally dedifferentiated and developed friable callus after 8-10 days of culture. Maximum number of somatic embryos / explant and higher percentage of response for somatic embryos formation have been found at $(2.5 \mathrm{mg} / \mathrm{L}) \mathrm{NAA}+(0.5 \mathrm{mg} / \mathrm{L}) \mathrm{TDZ}$ in leaf explants of M.arvensis (Fig -I) with the increase of NAA concentration up to $5.0 \mathrm{mg} / \mathrm{L}$ with $(0.5 \mathrm{mg} / \mathrm{L}) \mathrm{TDZ}$ within $25-30$ days of culture, globular, cotyledonary, and heart shaped embryos have formed directly on the surface of callus. But when the 
concentration of NAA was increased above $(3.0 \mathrm{mg} / \mathrm{L})$, percentage of response and somatic embryo induction were found decreased at higher concentration of NAA $(5.0 \mathrm{mg} / \mathrm{L})$ in combination with $(0.5 \mathrm{mg} / \mathrm{L}) \mathrm{TDZ}$. When the explants of primary somatic embryos were cut into fragments and cultured on the same induction medium secondary somatic embryos were induced within two weeks.

Table 1. Effect of various concentrations of $N A A$ and $(0.5 \mathrm{mg} / L) T D Z$ onSomatic embryo genesis from leaf explants of M.arvensis.

\begin{tabular}{llll}
\hline $\begin{array}{l}\text { Hormone conc } \\
\text { (mg/L) }\end{array}$ & $\begin{array}{l}\text { \%o of cultures } \\
\text { responding }\end{array}$ & $\begin{array}{l}\text { \%of Standard } \\
\text { Error } \\
\text { formation }\end{array}$ & $\begin{array}{l}\text { Average no of } \\
\text { Standard Error } \\
\text { /explants (S.E.)* }\end{array}$ \\
\hline NAA+TDZ & & & \\
$0.5+0.5$ & 73 & 31 & $6.7 \pm 0.3$ \\
$1.0+0.5$ & 80 & 50 & $6.9 \pm 0.5$ \\
$1.5+0.5$ & 90 & 60 & $10.7 \pm 0.3$ \\
$2.0+0.5$ & 92 & 76 & $12.0 \pm 0.54$ \\
$2.5+0.5$ & 94 & 80 & $15.0 \pm 0.5$ \\
$3.0+0.5$ & 85 & 70 & $13.0 \pm 0.6$ \\
$3.5+0.5$ & 75 & 65 & $11.0 \pm 0.4$ \\
$4.0+0.5$ & 70 & 60 & $9.0 \pm 0.5$ \\
$4.5+0.5$ & 65 & 58 & $7.0 \pm 0.4$ \\
$5.0+0.5$ & 60 & 50 & $5.0 \pm 0.5$ \\
\hline
\end{tabular}

*S.E. Standard Error
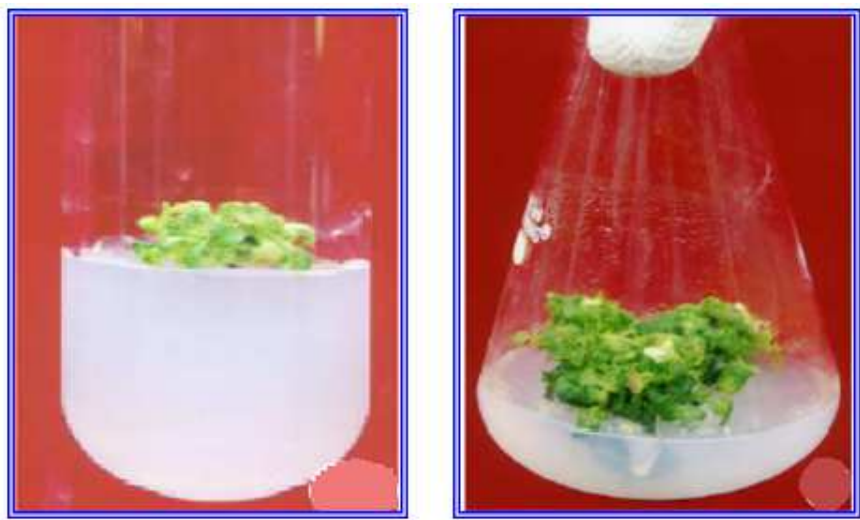

A

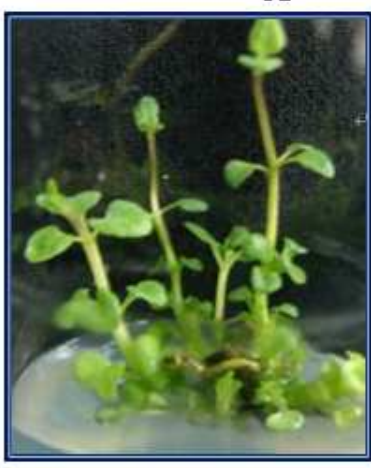

C plantlets in M.arvensis.

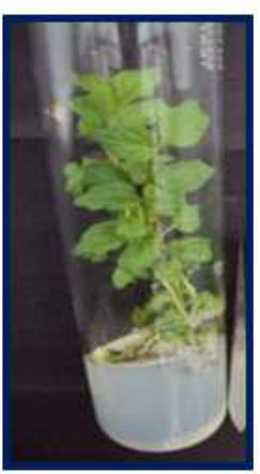

D
Table 2. Effect of NAA + TDZ on the conversion of somatic embryoids into

\begin{tabular}{lll}
\hline $\begin{array}{l}\text { Hormone conc } \\
(\mathbf{m g} / \mathrm{L})\end{array}$ & $\begin{array}{l}\text { \% of cultures } \\
\text { responding }\end{array}$ & $\begin{array}{l}\text { Average no of } \\
\text { shoots/embryods (S.E.)* }\end{array}$ \\
\hline NAA+TDZ & & \\
$0.5+0.5$ & 52 & $2.6 \pm 0.63$ \\
$0.5+1.0$ & 56 & $3.0 \pm 0.44$ \\
$0.5+1.5$ & 58 & $3.2 \pm 0.45$ \\
$0.5+2.0$ & 60 & $3.8 \pm 0.43$ \\
$0.5+2.5$ & 65 & $4.0 \pm 0.32$ \\
$0.5+3.0$ & 70 & $6.0 \pm 0.34$ \\
$0.5+3.5$ & 52 & $3.6 \pm 0.34$ \\
$0.5+4.0$ & 54 & $2.5 \pm 0.45$ \\
$0.5+4.5$ & 50 & $2.0 \pm 0.43$ \\
$0.5+5.0$ & 40 & $1.5 \pm 0.23$ \\
\hline
\end{tabular}

*S.E. Standard Error

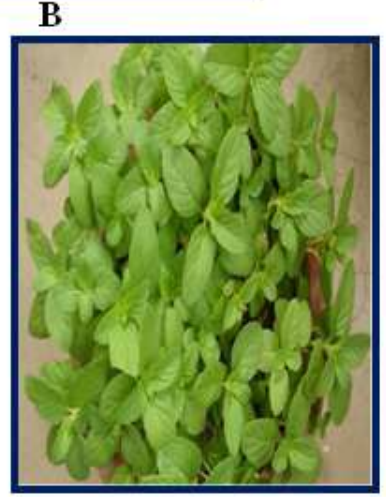

$\mathbf{E}$

Fig. 1. Somatic embryogenesis and plant regeneration in Leaf explants cultures of M.arvensis L. a) Embryogenic callus induction b) Maturation of Somatic embryos c) germination of somatic embryos, d) plant with normal shoot and root system developed from somatic embryos E) regenerated plantlets growing in Pot

Thus proliferation of somatic embryos occurred in two ways:

1. Multiplications of somatic embryos from the explants through primary somatic embryogenesis and

2. Proliferation of secondary somatic embryos from already formed 


\subsection{Germination of Somatic Embryos}

For germination, globular, heart and torpedo shaped embryos (a mixture) were transferred to MS medium supplemented with different concentration of auxin such as NAA $(0.5 \mathrm{mg} / \mathrm{L})$ in combination with $\mathrm{TDZ}(0.5-$ $5.0 \mathrm{mg} / \mathrm{L})$. Highest $(70 \%)$ frequency of embryo germination was noticed on a medium containing $(0.5 \mathrm{mg} / \mathrm{L})$ NAA in combination with $(3.0 \mathrm{mg} / \mathrm{L})$ TDZ. TDZand NAA were better for germination of somatic embryos in M.arvensis. When the concentration of BAP was increased above $(3.0 \mathrm{mg} / \mathrm{L})$, percentage of response and somatic embryo germination frequencies were decreased it was found that at higher concentration of TDZ $(5.0 \mathrm{mg} / \mathrm{L})$ in combination with $(0.5$ $\mathrm{mg} / \mathrm{L})$ NAA. Maximum number of somatic embryos germination and higher percentage of response for somatic embryos germination have been found at $(3.0 \mathrm{mg} / \mathrm{L}) \mathrm{TDZ}+$ $(0.5 \mathrm{mg} / \mathrm{L}) \quad \mathrm{NAA}$ in leaf explants derived somatic embryogenesis of M.arvensis (Table -2) (Fig-1-A,B and C).

\subsection{In Vitro Rooting}

Fully elongated healthy shoots were transferred on MS medium fortified with different concentration of IAA $(0.1 \mathrm{mg} / \mathrm{L})$ or IBA $(1.5 \mathrm{mg} / \mathrm{L})$.Profuse rhizogenesis was observed on MS medium produced roots (Fig-D).

\subsection{Acclimatization}

Rooted plantlets were removed from the culture medium and the roots were washed under running tap water to remove agar. Then the plantlets were transferred to polypots containing pre- soaked vermiculite and maintained inside a growth chamber set at $28^{\circ} \mathrm{C}$ and $70-80 \%$ relative humidity. After three weeks they were transplanted to poly bags containing mixture of soil + sand + manure in 1: $1: 1$ ratio and kept under shade house for a period of three weeks. The potted plantlets were irrigated with Hogland's solution every 3 days for a period of 3 weeks (Fig-E).

\section{Discussion}

Somatic embryogenesis is an important step in any successful plant transformation scheme. Stable transformation required that a single cell gives rise to a plant. The ideal transformation scheme is that via somatic embryogenesis, because from callus each transformed cell has the potential to produce a plant. Somatic embryogenesis and subsequent plant regeneration has been reported in most of the major crop species (Evans and Sharp, 1981). Soybean and cotton proved to be the most difficult to regenerate.

In the present investigation, the results on somatic embryogenesis have shown that auxin such as NAA (0.5$5.0 \mathrm{mg} / \mathrm{L} 0$ along with cytokininTDZ are essential for inducing the somatic embryogenesis from leaf explants of M.arvensis.A major factor for somatic embryogenesis is the nature of growth regulators used in the induction medium. The type of auxin or auxin in combination with cytokinin used in the medium can greatly influence somatic embryo frequency. The requirement of cytokinin in addition to auxin was observed in Sapindus trifoliatus (Desai et.al., 1986), Termineliaarjuna (Kumari et.al., 1998) and Psoralea corylifolia (Sahrawat and Chand, 2001) as it was observed in the present studies. Somatic embryo genesis was induced on medium containing NAA alone in Solanum melogena (Matsuoka and Hinata, 1979; Gladdle et.al., 1983; Sharma and Rajam, 1995).

Matsuokaand Hinata(1979) and Gleddle et.al., (1983) also observed a stimulatory effect of NAA on embryogenesis in eggplant hypocotyls explants as well as in leaf explants with carrot hypocotyls explant where somatic embryos were formed in response to a wide range of auxins including (IAA: NAA, 2,4-D, 2,4,5-T).

The embryogenesis action of NAA in egg plants were also different in another aspect where the role of auxin in embryogenesis species other than eggplant, induction and maturation of somatic embryos to the cotyledon stage was achieved on the same medium. The removal of NAA was required only for further development of embryos to plant lets and cotyledon explants grown on NAA exhibited globular shaped heart shaped and torpedo shaped stages. The embryogenic potential was markedly dependent on genotype isolated embryogenic callus from M.arvensis.

The sugars which supported callus proliferation on cotyledon explant i.e. sucrose, fructose, and glucose also supported embryogenesis, Somatic embryogenesis in NAA treated leaf explants was inhibited by cytokinins. Matsuoka and Hinate (1979) also observed cytokinin-induced embryogenesis in eggplant hypocotyls cultures. Ethylene also typically inhibited somatic embryogenesis (Ammirato 1983). The molecular aspects of embryogenesis, embryo specific proteins in carrot have been studied in rice (Chen and Luthe, 1987).Embryo specific proteins in somatic embryogenesis has been studied in alfaalfa (Stuat et.al., 1985). These developmental regulated genes are now being isolated from many plants (Choi et.al., 1987). BAP has been used for shoot induction of melon (Kathal et.al., 1986; Suesmatsu et.al., 1986; Dirks and Buggenum, 1989). The effect of BAP on somatic embryogenesis was tested by Oridate and Oosawa (1986) and the most efficient embryo formation was obtained at a concentration of $(0.1 \mathrm{mg} / \mathrm{L})$. The adventitious shoot formation and somatic embryogenesis in melon can be controlled by the ratio of auxins and cytokinin in the medium. In Coffea arabica somatic embryos also developed only when callus grown on 2,4 -D containing medium was transferred to 2,4-D free medium (Sondal and Sharp, 1977) and in pumpkin, NAA and IBA favored embryogenesis (Jelaska, 1974). In nucellus cultures of Vitis embryo formation occurred in the presence of NAA and BAP (Molling and Srinivasan, 1976).

The high frequency of multiple shoots was recorded from direct organogenesis of nodal explant. MS medium supplemented with benzyl adenine $(4.4 \mu \mathrm{M})$, kinetin $(4.6 \mu \mathrm{M})$, and $3 \%$ sucrose promoted the maximum number of shoots as well as beneficial shoot length in Paederia 
foetida (L.) (Thirupathi et.al., 2013)

Somatic embryogenesis is also preferred because it allows production of plant without somaclonal variation and in efficient cloning and genetic transformation (Sharp et.al., 1980). Synthetic seeds can also be developed by encapsulating somatic embryos in sodium alginate complex with calcium chloride as it was developed in Solanum melogena (Lakshmana Rao and Singh, 1991). Whereas Binzel et.al., (1996) reported that the entire process of induction and maturation of the embryos was completed on the same MS medium containing auxins and cytokinins (NAA+ TDZ) in $\mathrm{M}$ arvensis it was observed the requirement of both the hormones in the present investigations. Similarly somatic embryos maturation on MS medium containing the combination of auxins (NAA) and cytokinins (BAP) was observed in Cajanus cajan (Mallikarjuna et.al., 1996), Prunu saxivum (Garin et.al., 1997) and Hardiewickia binate (Chand and Singh 2001). Solanum surattensce (Ugandhar.2002). NAA and cytokinin (TDZ) was observed in Mentha piperita (Saha et.al.,2010)

Thus somatic embryogenesis always appeared to be dependent on the types of auxin/cytokinin/auxin+cytokinin and their concentration in the medium. The type of phytohormone and its concentration also varies from genotype to genotype. High concentration of auxin in combination with less concentration of cytokinin induced the somatic embryogenesis and maturation of somatic embryos in M.arvensis. But in the present study, a highest germination rate $70 \%$ was achieved. Plant lets with well developed shoot and root systems were washed carefully with tap water and transferred to plastic cups containing a mixture of vermiculite and soil for hardening. The acclimatized plantlets were successfully transplanted to pots under field conditions. Regenerated plants showed no observable morphological alteration.

During the present investigations, it was found that the high concentration of auxin in combination with less concentration if cytokinin induced the somatic embryogenesis and maturation of somatic embryos in M.arvensis. In conclusion, for induction of in vitro somatic embryo genesis the type of primary explant, choice of genotypes and hormonal concentration plays on important role (Patel et.al., (1994).

\section{References}

[1] Ammirato, P.V. (1983). The regulation of Somatic embryos development in plant cell cultures, suspension cultures technique and hormone requirements. Bio. Technol., 1: 68-74.

[2] Ammirato, P.V. (1987).Organisation events during Somatic embryogenesis. In: Plant Tissue \& Cell Culture, (Eds.). Green, C.E., Somers, D.A., Hackett, W.P. \& Biesboer, D.D. Alan R. Liss, Inc., New York, pp. 57-81.

[3] Binzel, M. L., Sanhla, A. N., Joshi, S. and Sankhla, D., (1996).:In vitro regeneration in chilli pepper (Capsicum annuum L.) from half-seed explant. Plant Growth Regulation, 20: $287-293$.
[4] Budavari, S., O’Neil, M. J., Smith, A. and Heckelmen, P. E. (1989).The Merk Index.An Encyclopedia of Chemicals, Drugand Biologicals.(11thEdition). Merck and Co., Rahway.

[5] Caissard,J.C., Faure, O., Jullien, F., Colson, M and Perrin, A.(1996).Adirect regeneration in vitro and transient GUS expression in Mentha piperita. Plant Cell Rep.16: 67-70.

[6] Cellarova, E.(1992).Micro-propagation of Mentha L.; In: Biotechnology in agriculture and forestry (ed.) Y P S Bajaj (Berlin, Heidelberg: Springer-Verlag) vol. 19, pp. 262-276

[7] Chand, S. and Singh, A.K. (2001).Direct somatic embryogenesis from zygotic embryos of a timber-yielding leguminous tree. Hardwickia binata Roxb.Curr. Sci., 80: 882888 .

[8] Chen, L.-J. and Luthe, D.S. (1987) Analysis of proteins from embryogenic and non-embryogenic rice (Oryza sativa L.) calk Plant Sci. 48, 181-188.

[9] Choi, J., Liu, L.S., Borkid, C. and Sung, Z.R.(1987). Cloning of developmentally regulated genes" Proc.Nat Acad. Sci 84: 1906- 1910

[10] Choi,Y.E., Kim,J.W and Soh, W.Y.(1987) Somatic embryogenesis and plant regeneration from suspension cultures of Acanthopanax koreanum. Plant Cell Rep., 17: 84-8.

[11] Desai,HV. Bhatt, P.N and Metha,A.R (1986) Plant Regeneration of Sapindus trifoliatus L. (Soap nut) through Somatic embryogenesis Plant Cell Rep.,3: 190-191.

[12] Dirks, R. and Buggenum, M.V. (1989). In vitro plant regeneration from leaf explants of Cucumis melo L, J. Plant. Physiol. 132: 373-377.

[13] Evans, D.A., Sharp, W.R. and Flick, Ch.E. (1981). Hand Book of Plant Tissue Culture Methods and Appl. in Agr.Culture. New York, London, pp: 45-113.

[14] Garin, E., Grenier, E. and Granier G.D. (1997) Somatic embryogenesis in wild cherry (Prunusauium).Plant Cell Tissue and Org. Cult.,48: 83-91.

[15] Gleddle, S., Keller, W. and Setterfield, G. (1983). Somatic embryogenesis and plant regeneration from leaf explants and cell suspensions of Solanum melongena (egg plants). Can. J. Bot., 61:656-665.

[16] Gulluce, M., Sahin, F., Sokmen, M., Ozer, H., Daferera, D.,Sokmen, A., Polissiou, M., Adiguzel, A. and Ozkan, H. (2007).Antimicrobial and antioxidant properties of the essential oils and methanol extract from Mentha longifolia L. Food Chemistry,103: 1449-1456.

[17] Jelaska, S. (1974).Embryogenesis and organogenesis in Pumpkin explants.Physiol . Plant. 31: 257-261.

[18] Karasawa, D. and Shimizu, S. (1980).Triterpene acids in callustissues from Mentha arvensis var. piperascens Agric. Biol. Chem. 44: 1203-1205.

[19] Kathal, R., Bhatnagar, S.P. and Bhojwani, S.S (1986). Regeneration of plants from leaf explants of Cucumis meloc.v. pusasharbati. Plant Cell Reports.7: 449-451.

[20] Kofidis, G., Bosabalidis, A. and Kokkini, S. (2006).Seasonal variations of essential oils in a linalool-rich chemotype of Mentha spicata grown wild in Greece.Journal of EssentialOil Research, 16; 469-472. 
[21] Kohlenbach, H.W. (1978).Camparative Somatic embryogenesis In: Frontiers of Plant tissue culture (Ed. Thorpe T.A.) Universal Calagry Press. pp. 59-66.

[22] Kukreja,A. K., Dhawan, 0.P., Ahuja, P. S., Sharma, S. and Mathur,A. K.(1992). Genetic improvement of mints: On the qualitative traits of essential oil of in vitro derived clones of Japanese mint (Mentha arvensis var. piperascens Holmes).J. Essent. Oil Res., 4: 623-629.

[23] Kumari,K.G., Ganesan,M and Jayabalan, N. (1996). Somatic organogenesis and plant regeneration in Ricinus communis. Biol. Plant.52:17-25.

[24] Lakhmana Rao, P.V. and Singh B. (1991).Plantlet regeneration from encapsulated somatic embryos of hybrid Solanum melongena L Plant Rep.10: 7-11.

[25] Lin M and Staba E J (1961) Peppermint and spearmint tissue cultures, callus formation and submerged culture; Lloydia (24) $139-145$

[26] Mallikarjun, N., Reena, M.J.T., Sastri, D.C. and Moss, J.P. (1996).Somatic embryogenesis in pigeon pea (Cajanus cajan). Indian J. Exptl. Biol., 34: 282-294.

[27] Matsuoka, H. and Hinata, K. (1979).NAA-induced organogenesis and embryogenesis in hypocotyls callus of Solanum melogena. L.J. Exptl. Bot., 30: 363-370.

[28] Mollins, M.G. and Sreenivasan, C. (1976). Somatic embryos and plantlets from on ancient clone of the Grape vine $(\mathrm{Cv}$ Cabernet Sauvignon) by apomixes In Vitro J.Exp. Bot., 27: 1022-1030.

[29] Moreno, L., Bello, R., Prime-Yufera, E., Esplugues, J. (2002).Pharmacological properties of the methanol extract from Mentha suaveolens Ehrh. Phytotherapy Research. 16: $10-13$.

[30] Murashige, T. and Skoog, F.(1962).A revised medium for rapidgrowth and bioassay with tobacco tissue cultures.Physiol. Plant., 15: 473-497.

[31] Oridate, T. and Oosawa, K.(1986).Somatic embryo genesis and plant regeneration from suspevsion callus culture in melon (Cucumis melo L.).Ja J. Breed., 36: 424 - 428.

[32] Pandya, H. A. and Saxena, O. P. (2000). "Role of PGRs on tissue culture raised plantlets of Gladiolus, Chrysanthemum and Lily" (abstr) Role of plant growth regulators and plant biotechnology to improve growth and productivity of plants, Botany Department, Gujarat University, Ahmedabad, India.

[33] Patel, M.B., Bhardwaj, R. and Joshi, A. (1994).Organogenesis in Vigna radiates L. Wilczek" Indian J. Exp. Biol. 29: 619622 .

[34] Rech,E.L. andPires, M. J. P.(1986) Tissue culture propagation of Mentha sps.by the use of axillary buds Plant Cell Rep. 5:718 .
[35] Reed, B. M. (1999).In vitro storage conditions for mint germplasm. Hort. Sci. 34: 350-352.

[36] Roberts, A.V., Yokoya, K., Walker, S. and Motley, J. (1995). Somatic embryogenesis in woody plants (Eds) Jain, S., Gupta, P. Newton, R.) Kluwer Academic Publishers, The Netherlands, pp. 277-289.

[37] Sato, S., Newell, C.Kolacz, K. and Tredo, L. (1993). Stable transformation via particle bomardment in two different soybean regeneration systems.Plant cell Rep.12: 408-413.

[38] Saha. S Ghosh P. D and Sengupta. C (2010) "In Vitro Multiple Shoot Regeneration of Mentha piperita," Journal of Tropical Medicinal Plants, Vol. 11, pp. 89- 92,

[39] Sahrawat AK and Chand S (2001) Continuous somatic embryogenesis and regeneration from hypostyle segments of Psoralea corylifolia Linn: An endangered and medicinally important Fabaceae plant. Curr. Sci. 81:1328-1331.

[40] Sharma, P. and Rajam M.V. (1995). Genotype, explant \& position effects on organogenesis \& Somatic embryogenesis in eggplant (Solanum melongena L.) J. Exptl. Bot., 46: 135141.

[41] Sharp, W.R., Sondehl, M.R., Caldas, L.S. and Maraffa, L.S. (1980). The physiology of In vitro a sexual embryogenesis Hort. Rev. 2: 268-310.

[42] Sondahl, M.R. and Sharp W.R. (1977). High frequency of induction somatic embryos in cultured leaf explants of coffea arabica L. Z. Pflanzen Physiol., 81: 395-408.

[43] Stuart, D.A., Nelsen, J., Strickland, S.G. and Nichol, J.W. (1985). Factors affecting developmental processes in alfa alfa cell culture. In: Tissue culture in Forestry \& Agriculture. R.R. Henke, K.W. Hughes, M.P. Constantin and A. Hollaender (Eds). Pp. 58-73.

[44] Suesmatso, N., Ootsuka, H. and Toda, M. (1986). Bull. Schizuoka.Agr. Exp.Stone. 31: 31-38.

[45] Thirupathil.M Srinivas.D and Jaganmohan Reddy (2013) High frequency of multiple shoots induction in Paederia foetida (L.)- A rare medicinal plant 2013 Science publishing Group 1(5):60-65

[46] Ugandhar T. (2002). Tissue culture studies in Solanam surattense Ph.D.Thesis, Kakatiya University, Warangal, (T.S).

[47] Van Eck,J. and Kitto,S.L. (1992).Regeneration of peppermint and orange mint from leaf disks. Plant Cell Tiss.Org. Cult., 30: 41-46.

[48] Yadegarinia, D., L. Gachkar, M. B. Rezaei, M. Taghizadeh, S. A.Astaneh, I. and Rasooli. (2006). Biochemical activities of Iranian Mentha piperita L. and Mentha communis L., essential oils. Phytochemistry, 67, 1249-1255. 